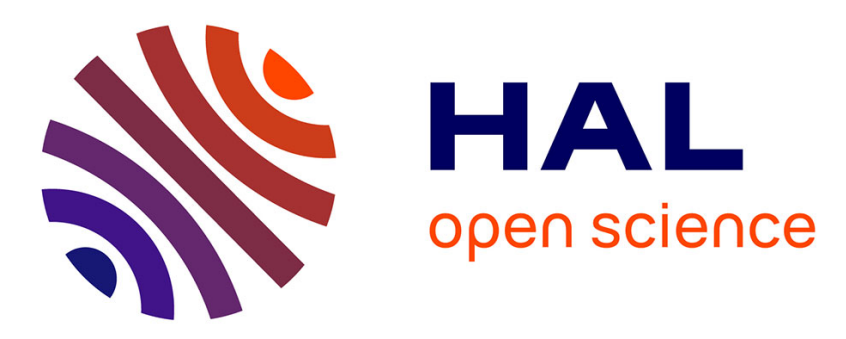

\title{
Protective effect of endolithic fungal hyphae on oolitic limestone buildings
}

Nicolas Concha Lozano, Pierre Gaudon, Jacques Pagès, Gisel de Billerbeck, Dominique Lafon, Olivier Eterradossi

\section{- To cite this version:}

Nicolas Concha Lozano, Pierre Gaudon, Jacques Pagès, Gisel de Billerbeck, Dominique Lafon, et al.. Protective effect of endolithic fungal hyphae on oolitic limestone buildings. Journal of Cultural Heritage, 2012, 13 (2), pp.120-127. 10.1016/j.culher.2011.07.006 . hal-00782521

\section{HAL Id: hal-00782521 \\ https://hal.science/hal-00782521}

Submitted on 30 Jan 2013

HAL is a multi-disciplinary open access archive for the deposit and dissemination of scientific research documents, whether they are published or not. The documents may come from teaching and research institutions in France or abroad, or from public or private research centers.
L'archive ouverte pluridisciplinaire HAL, est destinée au dépôt et à la diffusion de documents scientifiques de niveau recherche, publiés ou non, émanant des établissements d'enseignement et de recherche français ou étrangers, des laboratoires publics ou privés. 


\title{
Protective effect of endolithic fungal hyphae on oolitic limestone buildings
}

Nicolas Concha-Lozano ${ }^{a}$, Pierre Gaudon ${ }^{a}$, Jacques Pages ${ }^{b}$,

Gisel de Billerbeck ${ }^{c}$, Dominique Lafon ${ }^{a}$, Olivier Eterradossi ${ }^{\text {a }}$

${ }^{a}$ CMGD, école des Mines-d'Alès, 6, avenue de Clavières, 30319 Alès cedex, France

${ }^{\mathrm{b}}$ Association mousses et lichens du Haut-Languedoc, Hameau-La-Gineste, 34610 Rosis, France

${ }^{\mathrm{c}}$ Laboratoire Elios, 2, rue Crébillon, 30900 Nîmes, France

Original article :

N. Concha-Lozano, P. Gaudon, J. Pages, G. de Billerbeck, D. Lafon, O. Eterradossi. Protective effect of endolithic fungal hyphae on oolitic limestone buildings. Journal of Cultural Heritage. (2012) 13(2):120-7

Keywords: Stone / Monument / Durability / Lichens Patina / Capillary / Gypsum

\begin{abstract}
This study presents characterizations of weathering forms of the same oolitic limestone from four quarries and eight monuments exposed on various environmental conditions focusing on the water-proofing effect of endolithic organic matter. Patinas were analyzed by X-ray diffraction (XRD), scanning electron microscopy with energy dispersive X-ray spectrometry (SEM-EDX), capillarity coefficient through weathered and unweathered sides, gypsum content and porous network morphology by epoxy resin molding. Study of weathering forms on old quarries indicates that lichens colonization (Verrucaria nigrescens and Caloplaca aurantia) can fill the superficial porous network with a dense network of lichenised fungal hyphae. Capillary coefficient measurement on natural and calcinated samples showed that endolithic organic matter can waterproof the stone and could act as a sulfate contamination barrier. Similar endolithic organic layer due to ancient lichens growth are found on some antique monuments of the Nîmes downtown and could explain their well-preserved state, unlike decayed 19th century churches that were never colonized by lichens.
\end{abstract}




\section{Research aims}

This study focuses on a recurring debate about the development of patinas and their role in the protection or acceleration of buildings deterioration [1-3]. It is commonly accepted that weathered forms-or patinas-depend on environmental factors around the exposed surfaces, such as water and aerosols exposure [4,5]. Paradoxically, in the central city of Nîmes some monuments built with the same oolitic limestone are well preserved while others are severely degraded despite of their similar environmental conditions. Two types of weathering are observed. On one hand, several monuments (e.g. 19th century churches) are remarkably damaged, suffering blistering, yellowing and granular disintegration according to ICOMOS glossary [6]. On the other hand, monuments even much older (e.g. the roman temple Maison Carrée) and located in the same neighborhood do not exhibit such severe degradations. The main objective of this study is to further understand these observed weathering paths divergences, focusing particularly on the bioprotective role of lichens. For this, microstructure, composition and water transfer properties of patinas were studied on Bois des Lens oolitic limestone samples collected on 12 different sites.

\section{Introduction}

Bois des Lens stone is a white and fine-grained oolitic limestone commonly used for building and sculpture over 20 centuries in southern France. Its exploitation and use as a building stone started in about the 4th BC century and its dissemination in the antic architecture extends over a large part of French Mediterranean coast (Narbonne, Beziers, Arles, Frejus, Nice) [7,8]. This early cretaceous sedimentary rock is extracted from massive outcrops that allow blocs size up to several meters. At the macroscopic scale, the stone has a smooth feel, bright uniform color and invisible bedding. Due to its isotropic mechanical properties the stone is appreciated for ornamental architecture and sculpture. Its relatively high porosity (inter-and intra oolitic voids) does not allow a glossy polish but a fine softened surface. The peculiarity of this stone is that its patina extends up to several millimeters in depth, which is the cause of a great diversity of appearance in terms of color and texture after aging [9]. Patinas can be composed by several layers like deposits and sub-surfaces modifications depending on reversible or irreversible weathering mechanisms [10]. Surface deposits layers are composed by air born particles, aerosols, salts precipitation, or epilithic bio-logical colonization weakly adherent to the mineral substrate and easily removable. Sub-surface modifications are 
described as the location of irreversible aging mechanisms like structural and com-position change. In this study, the patina is defined as the layer affected by irreversible aging that cannot be removed by conventional cleaning processes such as laser or sandblasting. Decrease of erosion rate due to protective microorganism inter-face between the stone and its environment is an example of the bioprotection concept [11]. According to Carter and al. [12], bioprotection is a little know-earth surface processes in comparison with the vast literature on lichen biodeterioration. Although deterioration mechanisms by lichens are well known $[13,14]$, it is unclear whether the weathering rate would be lower without them, especially in a polluted urban environment. Recent field studies gave evidence of the protective effect of lichens [15-17] highlighting that biodeterioration is slower than physicochemical process. The main bioprotection mechanism is often called "umbrella effect" illustrating that lichens thallus forms a barrier layer that reduces the amount of runoff water in contact with stones $[12,17]$, but also protects the surface from wind erosion and reduces thermoclastic damaging due to intermittent solar radiation $[2,18]$. This study focuses on a second type of bioprotection mechanism, due to the presence of organic matter entrapped beneath the surface of the stone, even after complete removal of epilithic biological colonization by cleaning.

\section{Materials and methods}

\subsection{Sampling method}

All samples were collected from monuments and quarries of Languedoc-Roussillon region, located in the South of France. To ensure that samples have a similar lithology, a previous literature review was conducted to identify monuments and quarries of Bois des Lens stone. An initial list of 13 monuments and one quarry was extracted from the MONUMAT database [19]. MONUMAT database is a tool developed by the French geological survey (BRGM), which contains an inventory of the main historic monuments, the stones used for their construction and location of the quarries. This information is accessible for all users involved in historical heritage conservation (architect, local authorities, companies specializing in conservation, etc.) through a web interface [19]. Among the initial list of buildings identified, only eight were selected after petro-graphic verification and their potential for sampling (Table 1). The localization of the three antique quarries (Rocamat antique, Pielles quarry and Roquet quarry) was suggested by the work of archaeologist Bessac who studied the history of extraction techniques of Bois des Lens stone [7,8]. The quarries are located on the oolitic 
facies identified under n4bU (Barremian age) according to the BRGM geo-logical map of Sommière [20]. The sampling of the 19th century churches was done with a scalpel on representative areas according to procedures used in previous studies [21,22]. Samples of the Maison Carrée (MC1), come from the western facade and were collected as the opportunity of a restoration project. Sample MC1-3 was collected on the internal side of removed rubble and considered as an unweathered reference state (Table 1).

Tab. 1, Sampled sites of Bois des Lens oolitic limestone with their location, age, and car traffic exposure indication.

\begin{tabular}{lllll} 
Samples & Sites & Locality & Years of exposition & Traffic exposition \\
\hline MC1 & Maison Carrée & Nîmes & Ist Century & High \\
MC1-2 & Maison Carrée & Nîmes & Ist Century & High (sanded) \\
MC1-3 & Maison Carrée & Nîmes & Ist Century & Not exposed \\
TD3 & Temple of Diana & Nîmes & Ist Century & High \\
RQ2 & Roquet quarry & Moulezan & Roman & Low \\
PI3 & Pielles quarry & Combas & Roman - XVth & Low \\
ROA & Rocamat antique & Moulezan & Roman & Low \\
SG2 & Abbey of St Gilles & St Gilles & 12 th Century & Medium \\
EB3 & ST Baudile church & Nîmes & $1867-1877$ & High \\
EPO & Pompignan church & Pompignan & 1850 & Medium \\
MMF & War memorial & Fons & 1920 & Low \\
EP2 & St Perpetue church & Nîmes & $1852-1862$ & High \\
SP2 & St Paul church & Nîmes & $1835-1849$ & High \\
RA & Rocamat quarry A & Moulezan & 2009 & low \\
RB & Rocamat quarry B & Moulezan & 1996 & Low \\
RC & Rocamat quarry C & Moulezan & $1990 \pm 2$ & Low \\
RD & Rocamat quarry D & Moulezan & $1960 \pm 10$ & Low \\
RD-2 & Rocamat quarry D & Moulezan & $1960 \pm 10$ & Low (sanded) \\
\hline
\end{tabular}

\subsection{Physicochemical characterizations}

Each sample was sawn with a diamond disc perpendicular to the exposed surface. Samples were immersed in epoxy resin under vacuum and then finely polished for examination with an environmental scanning electron microscope (QUANTA 200 FEG, FEI Company). Petrographic analysis of minerals, grain joints and size was conducted by crossed nicols optical microscopy (LEITZ Labor-lux 11 POL S) on $30 \mu \mathrm{m}$ thin section. For mineralogical and chemical analysis, we used blades of rock obtained by microtome or powder obtained by rasp. Mineralogical composition was analyzed by X-rays diffraction (BRUCKER AXS D8 ADVANCE) on first $4 \mathrm{~mm}$ powdered patinas. The distribution of sulfur and calcium has been mapped on the first $2 \mathrm{~mm}$ with EDX (INCA X-ray microanalysis). Distribution of sulfur was 
mapped in order to compare the gypsum contamination depth through the patina with a similar procedure adopted in previous studies [1]. Gypsum content (wt. \%) was estimated from electric conductivity (JETWAY 4510) of unsaturated solution of powdered first $4 \mathrm{~mm}$ patinas in deionized water using a calibration curve. The electric conductivity calibration curve was obtained from synthetic solutions saturated in respect to calcite with several amounts of solubilized gypsum assuming that the solubility of calcite $\left(\mathrm{Ksp}=9.8 \times 10^{-9}\right)$ is negligible compared with that of gypsum $\left(\mathrm{Ksp}=2.4 \times 10^{-5}\right)$ and that gypsum is the only soluble salt (supported by XRD and EDX measurement). Lichen genus was identified by binocular microscopy (LEICA WILD M10) on hymenial layer extracted from mature fungal fructification. Fruiting bodies were extracted from patinas using a pin and then cut in half by a razor blade.

Tab. 2, Uniformity of the Bois des Lens stone in spite of the different sampling location. Petrophysical properties of unweathered samples in the commercial quarry (RA), on antique quarrys (PI3 and RQ2) and on the Maison Carrée (MC1-3).

\begin{tabular}{lllll} 
Petrophysical properties & RA & PI3 & RQ2 & MC1-3 \\
\hline Minerals & $\begin{array}{l}\text { Calcite, } \\
\text { Quartz }\end{array}$ & Calcite & $\begin{array}{l}\text { Calcite, } \\
\text { Quartz }\end{array}$ & $\begin{array}{l}\text { Calcite, } \\
\text { Quartz }\end{array}$ \\
\hline Ca (\% atom.) & 19,9 & 20,0 & 20,0 & 20,0 \\
C (\% atom.) & 19,8 & 19,9 & 19,4 & 19,5 \\
O (\% atom.) & 59,6 & 59,8 & 59,1 & 59,2 \\
Si $(\%$ atom.) & 0,6 & 0,3 & 1,3 & 0,9 \\
Other Elements $(\%$ atom.) & 0,0 & 0,0 & 0,3 & 0,4 \\
\hline Density $\left(\mathrm{g} . \mathrm{cm}^{3}\right)$ & $2.2-2.3$ & 2.23 & 2.26 & 2.21 \\
Total porosity $(\%)$ & $13-17$ & $15-16$ & $15-17$ & $15-16$ \\
Water accessible porosity & $11-14$ & $13-13$ & $12-14$ & $13-13$ \\
Capillary coef. $\left(\mathrm{g.cm}\right.$. $\left.^{-2} \mathrm{~s}^{-0.5}\right)$ & $60-90$ & $82-79$ & $68-75$ & $70-72$ \\
\hline
\end{tabular}

\subsection{Pore network molding}

As the stone is composed of almost pure calcium carbonate, a molding of porosity was performed by resin impregnation and calcite crystals dissolution. Dried samples were impregnated with epoxy resin under vacuum (around 10-2 Pa). After resin polymerization, samples were finely polished and then immersed in a $30 \% \mathrm{HCl}$ solution. Once the dissolution reaction was completed, the samples were extensively washed in pure water and then dried in open air. Total dissolution of calcite was confirmed by EDX calcium quantification performed on molded samples. 


\subsection{Water transfer properties}

Test samples were cut into cuboids of $1.5 \times 1.5 \times 4 \mathrm{~cm}$ with one weathered side. Two samples were sandblasted (quartz sand under 4 bar pressure) in order to remove the superficial biological colonization (on sample RD-2) or any traces of lime whitewash that could be applied during previous restoration work (on sample MC1-2). Capillary coefficients were measured four times for each sample with deionized water: first on weathered and unweathered faces and then after calcination on both sides. Calcination was performed in an oven at $500{ }^{\circ} \mathrm{C}$ for $20 \mathrm{~min}$ in order to remove the intraporous organic matter. Standard capillary measurement protocols (e.g. EN 1925) were not suitable for measurement through thin stratified materials like patinas $(<1 \mathrm{~mm})$ due to the fact that contact between the sample and the free water must be precisely controlled to pre-vent absorption of water through the unweathered sample sides. So, an automatic monitoring soaked volume apparatus was used (KSV INSTRUMENT LPR 902) whose scheme is shown in Fig. 1. Capillarity coefficient C [g m-2 s-0.5] was calculated using:

$C=\frac{V_{t_{1}}-V_{t_{0}}}{S \cdot \sqrt[2]{t_{1}-t_{0}}}$

with $\mathrm{Vt}$ the volume soaked at the time $\mathrm{t}$ through the surface $\mathrm{S}$. Imbibitions duration was 30 min with an acquisition frequency of $1 \mathrm{~Hz}$. Sample were dried in an oven at $60 \circ \mathrm{C}$ for $12 \mathrm{~h}$ before each capillarity measurement. To reach a comparable initial saturation index, calcinated samples were previously immersed in water and dried under the same conditions than non-calcinated samples. 


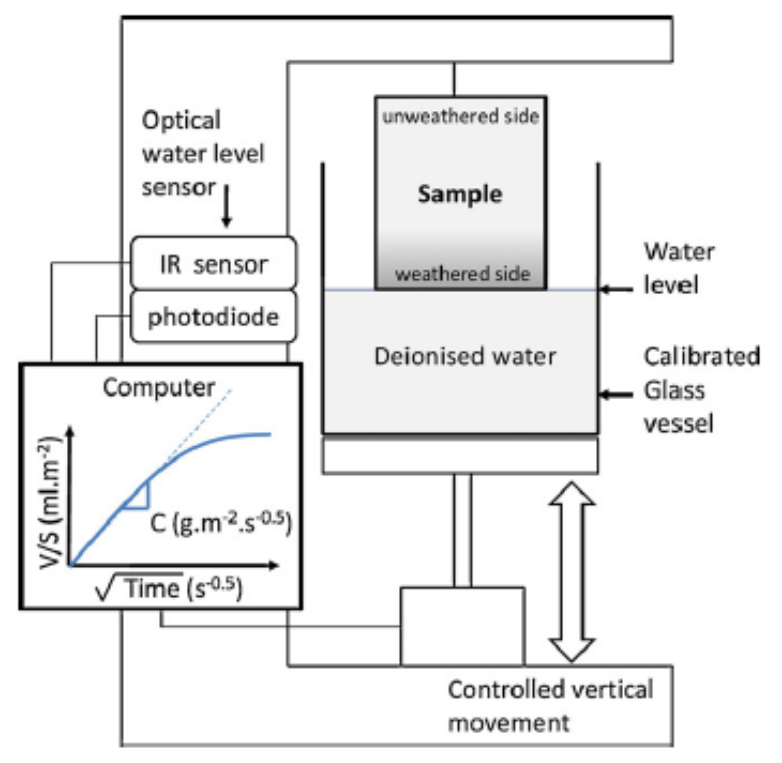

Fig. 1. Scheme of the used automatic monitoring soaked volume for capillarity measurement (KSV INSTRUMENT LPR 902). Here the sample is positioned for the weathered side capillary measurement.

\section{Results and discussions}

\subsection{Petrophysical properties of unweathered Bois des Lens oolitic limestone}

Table 2 summarizes some petrophysical characteristics of four samples of different provenances (three quarries and one monument) in order to estimate the natural variability of the Bois des Lens stone facies. The petrophysical properties uniformity at the initial state (unweathered) is a necessary condition for a comparative aging study. Unweathered Bois des Lens stone is composed of quasi-pure calcium carbonate. Only calcite and traces of quartz are detected by DRX. However, quartz content is low with respect to calcite since less than $1.3 \%$ atom are silicon (Table 2). Thin sections show well-sorted rounded oolites whose diameter ranges from 0.2 to $0.6 \mathrm{~mm}$. Oolites nucleus are composed by foraminifer-ous fragments and surrounded by a layered micritic cortex (Fig. 2). Oolites are weakly compacted and cemented by a micritic matrix with some sporadic sparite crystals. Imbibition test give an open porosity of $11-14 \%$ and a total porosity of $13-17 \%$ (Table 2). Although there are slight variations in petrographic properties, studied samples can be considered homogenous despite their different sampling location. 


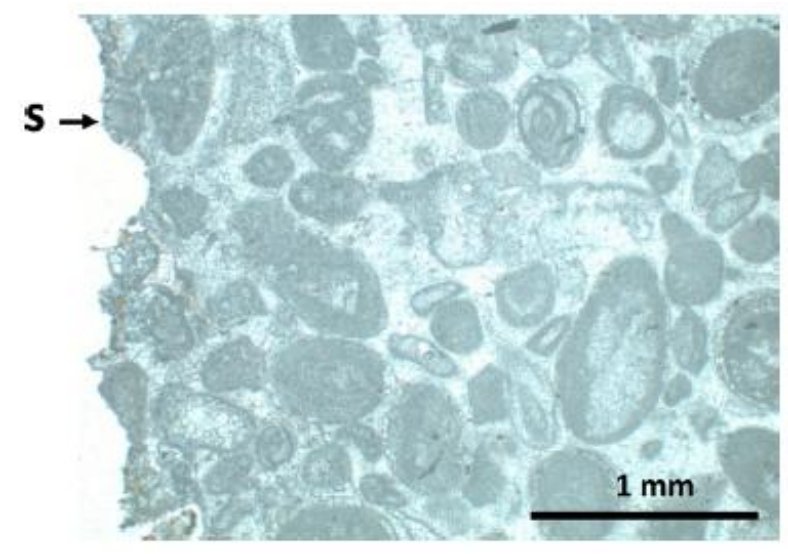

Fig. 2. Ooide grainstone texture of Bois des Lens cretaceous limestone viewed by transmission microscope on a thin section, sample (MC1). S: exposed surface. Note that evidence of endolithic biological colonization is not visible.

\subsection{Weathering forms of well-preserved building}

The patina of the Maison Carrée is a characteristic example of low erosion and good mechanical cohesion weathered form. The patina is composed of several layers beneath the stone sur-face (Fig. 3a). The deepest layer located from 3 to $0.5 \mathrm{~mm}$ deep is a brownish or sometimes greenish layer. It's boundary with unaltered rock is diffuse and is always associated with a dense hyphae network (Table 3). Analysis of thin sections shows that the weathered zone is not a deposit or an encrustation but a superficial transformation since oolitic structure is visible from the unweathered area until the exposed surface (Fig. 2). Nevertheless, the oolitic grain density seems to be lower at $1 \mathrm{~mm}$ deep, which implies a change in the petrographic texture and supports the existence of endolithic dissolution of calcite. As shown in Fig. 4c, the molded porosity shows a high density of micrometric tubes. This structural transformation of the rock could be the result of a dissolution/ precipitation activity of endolithic lichen hyphae. A calcite structure is still visible even in the most invaded area (voids in Fig. 4c) that contributes to the mechanical cohesion of the patina [27]. Nevertheless, this layer has lost its microporosity visible on the initial oolitic cortex. This implies that all the pores are filled with hyphae. Above the brownish layer, a thinner and lighter layer was observed which structure is petrographically nearly identical to that of the unweathered side. Although this superficial layer is thin (about 500 microns) it gives an unweathered appearance whereas the patina is deeply invaded by biological colonization. A deposit rich in sulfur from about 100 microns thick covers the patina. This deposit is the cause of the Maison Carrée blackening. The origin of sulfur is attributed to an urban source of 
contamination since monuments located in rural area (defined as an area of low car traffic) do not contain gypsum (Table 5). Table 3 shows that patinas sampled in quarries or on wellpreserved buildings share some common points. For example, macroscopic observations on sample MC1 and RD show that both have the same indurated brownish layer (Fig. 3a and b). The MEB images of pore resin molding (Fig. 4c) point out that brownish layer is associated with the presence of lichen hyphae. Likewise, for all other samples, the lichen hyphae layer is the discriminating attribute between the protective and deteriorated patinas (Table 5). In quarries, stones of more than 20 years of exposure are firstly covered with black lichen Verrucaria nigrescens (Fig. 5) and then a second type of lichen Caloplaca aurantia appears on samples exposed for over 50 years (Table 3).

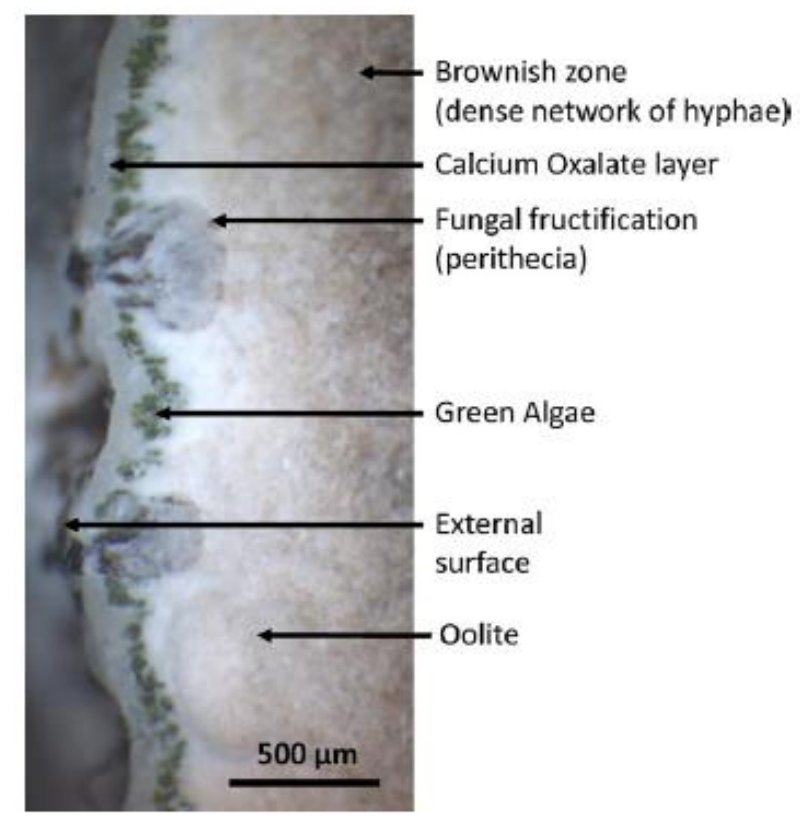

Fig. 3. Microphotograph of a weathered side profile (antique quarry RQ2) showing the oolitic limestone interface with Verrucaria nigrescens lichen fructification.

\subsection{Weathering forms of deteriorated buildings}

A link can be established between the gypsum content and the appearance of blisters and crumbling. All deteriorated buildings contains high load of gypsum upper than $15 \%$ wt. in their first $4 \mathrm{~mm}$ (sample EB3, EPO, and SP2, in Table 5). Below this gypsum content, the stones do not desquamate, and no erosion of their surface is visible (e.g. SG2, EP0, TD3 and $\mathrm{MC}$, in Table 5). However it is necessary to distinguish between the superficial deposits of 
gypsum (as a black crust of Maison Carrée, MC1) and the deep contamination as the churches of Nîmes (EB3, EP2, SP2). In the first case (Fig. 4a and b), the gypsum is mixed with the carbonaceous material deposited in thin layers of 0,5 to $1 \mathrm{~mm}$ weakly adherent to the stone surface with an entry of sulfur that does not exceed $500 \mu \mathrm{m}$. This superficial layer is only responsible of the monument darkening but not of the mechanical decohesion. In the second case (Fig. 4d and e), microcrystals of gypsum are detected up to several centimeters deep, associated with blistering, disintegration, and yellowing. Fig. 4 shows a clear grain shape modification of the sulfur-contaminated stone (SP2, St Paul church) whose grains appear smaller than in the Maison Carrée. In addition, oolites and biodetritic elements (Fig. 4d) are no longer visible. This change may be due to carbonate replacement by gypsum crystals since limestone is the only source of calcium [23-25]. The decrease of calcite ratio also explains weakness, disintegration and swelling of the monuments, which contain gypsum ratio upper to $15 \%$ wt [26]. 
Tab. 3, Description by layers of weathered forms (patinas) classified into three categories: well-preserved, damaged and aged in a quarry.

\author{
Description of patinas layers: \\ fist layer \\ third layer
}

Sample Site second layer

\begin{tabular}{|c|c|c|}
\hline \multicolumn{3}{|c|}{ Deteriorated samples } \\
\hline EB3 & ST Baudile church & $\begin{array}{l}\text { Granular disintegration, yellowing } \\
\text { Cracking, dechoesion and blistering }\end{array}$ \\
\hline EP2 & St Perpetue church & $\begin{array}{l}\text { Granular disintegration, yellowing } \\
\text { Cracking, loss of grains cohesion and desquamation of } 5 \mathrm{~mm} \text { thick plates }\end{array}$ \\
\hline $\mathrm{SP} 2$ & St Paul church & $\begin{array}{l}\text { Granular disintegration, yellowing } \\
\text { Fissuration, loss of grains cohesion and blistering }\end{array}$ \\
\hline EPO & Pompignan church & Coloration (yellowing) and slight loss of cohesion \\
\hline \multicolumn{3}{|c|}{ Well preserved samples } \\
\hline MC1 & Maison Carrée & $\begin{array}{l}0-100 \mu \mathrm{m} \text { : superficial deposit of black gypsum crust } \\
100-500 \mu \mathrm{m} \text { : well preserved layer } \\
\text { Endolitic hyphae network (Brownish layer) }\end{array}$ \\
\hline MC1-2 & Maison Carrée & $\begin{array}{l}100-500 \mu \mathrm{m}: \text { well preserved layer } \\
\text { Endolitic hyphae network (Brownish layer) }\end{array}$ \\
\hline MC1-3 & Maison Carrée & No patina \\
\hline TD3 & Temple of Diana & $\begin{array}{l}0-100 \mu \mathrm{m} \text { : superficial deposit of black gypsum crust } \\
100-500 \mu \mathrm{m} \text { : well preserved layer } \\
\text { Endolitic hyphae network (Brownish layer) }\end{array}$ \\
\hline SG2 & Abbey of St Gilles & $\begin{array}{l}\text { 0-300 } \mu \mathrm{m} \text { black/grey superficial deposit of gypsum } \\
\text { Endolitic hyphae network (Brownish) }\end{array}$ \\
\hline MMF & War memorial & $\begin{array}{l}\text { Indurated layer with biopitting } \\
\text { Endolitic hyphae network (green) }\end{array}$ \\
\hline
\end{tabular}

\title{
Quarry samples
}

\begin{tabular}{|c|c|c|}
\hline RA & Rocamat quarry A & No patina \\
\hline $\mathrm{RB}$ & Rocamat quarry B & Removable dust \\
\hline $\mathrm{RC}$ & Rocamat quarry $\mathrm{C}$ & 0-100 $\mu \mathrm{m}$ Epilithic colonization : Verrucaria lichens (Black) \\
\hline RD & Rocamat quarry D & $\begin{array}{l}\text { Epilithic colonization: Thales of Caloplaca Aurantia (orange) and Verrucaria lichens } \\
\text { (Black) } \\
\text { Weddellite spots } \\
\text { Endolitique hyphae network (Brownish or green) zone }\end{array}$ \\
\hline RD-2 & Rocamat quarry D & Endolitique hyphae network (Brownish or green) zone \\
\hline RQ2 & Roquet quarry & $\begin{array}{l}\text { Epilithic colonization: Thales of Caloplaca Aurantia (orange) or Verrucaria lichens } \\
\text { (Black) } \\
\text { spots of } 100 \mu \mathrm{m} \text { Oxalate crust (weddellite) } \\
\text { Green algae and lichens fructification (perithès) } \\
\text { Endolitique hyphae network (brownish or green) }\end{array}$ \\
\hline PI3 & Pielles quarry & $\begin{array}{l}\text { Epilithic colonization : Caloplaca Aurantia } \\
\text { Weddellite spots } \\
\text { Dense hyphae network }\end{array}$ \\
\hline ROA & Rocamat antique & $\begin{array}{l}\text { Epilithic colonization: Verrucaria lichens (Black) } \\
2 \mathrm{~mm} \text { of dense hyphae network }\end{array}$ \\
\hline
\end{tabular}




\subsection{Waterproofing effect of intraporous organic matter}

As shown in Table 4, capillary tests through unweathered sides show similar capillary coefficient with regards to the small standard deviation $(4,1)$ over average value $(75,0)$ ratio. This uniformity of water transfer behavior at the initial states that is a crucial pre-requisite for any comparative aging study [27]. Regarding capillary coefficient through weathered sides, a wide variation is observed in accordance with the wide diversity of patinas described in Table 3. A waterproofing index WINDEX (\%) can be calculated in function of the capillary coefficients of the unweathered CU and weathered CW sides:

$W_{I N D E X}=\frac{C_{U}-C_{W}}{C_{U}} \times 100$

An index close to 100 , characterizes a highly impermeable patina, while an index close to 0 means no waterproofing effect. A waterproofing index of 0 was assigned to deteriorated patinas since their low cohesion cannot provide any protective effect. Table 5 shows that there are two types of patina according to the waterproofing index. Patinas with a low waterproofing index $(<14.6)$ are samples recently exposed and not covered with lichens. Patinas of the second category have a high waterproofing index (> 87) and contain organic matter although some are not covered by a biological colonization (MC1, TD3, SG2 and MMF, in Table 3). This waterproofing effect is mainly attributed to the entrapped organic matter that fills pores and leads to a hydraulic conductivity drop. This assumption is supported by the close capillarity coefficient value of weathered and weathered-calcinated sides (Table 4) since organic matter was removed by the calcination treatment. Note that the capillarity coefficient of unweathered and unweathered-calcinated sides remains unchanged, so the calcination treatment does not modify the initial capillary coefficient of the stone. The effect of dirt, dust or traces of ancient lime whitewash on waterproofing is negligible, considering that they are removed by sandblasting. Indeed, waterproofing index differences between nonsanded and sanded patina on samples MC1 and RD are not representative since they are $4 \%$ and 3\% respectively (Table 5), which is below the accuracy of capillary measurements estimated around 5\% (Table 4). 
Tab. 4, Capillary coefficient through both weathered and unweathered sides before and after organic matter removal by calcination

\begin{tabular}{|c|c|c|c|c|c|}
\hline \multirow[b]{2}{*}{ Samples } & \multirow[b]{2}{*}{ Sites } & \multicolumn{4}{|c|}{ Capillary coefficient $\left(\mathrm{g} \cdot \mathrm{m}^{-2} \cdot \mathrm{s}^{-1 / 2}\right)$} \\
\hline & & $\begin{array}{l}\text { Unweathered } \\
\text { side }\end{array}$ & $\begin{array}{l}\text { Weathered } \\
\text { side }\end{array}$ & $\begin{array}{l}\text { Weathered } \\
\text { side after } \\
\text { calcination }\end{array}$ & $\begin{array}{l}\text { Unweathered } \\
\text { side after } \\
\text { calcination }\end{array}$ \\
\hline $\mathrm{MC1}$ & Maison Carrée & 70,50 & 5,3 & 68,4 & 71,2 \\
\hline MC1-2 & Maison Carrée & 71.3 & 8.3 (sanded) & 72.6 & 68.4 \\
\hline TD3 & Temple of Diana & $*$ & $*$ & $*$ & $*$ \\
\hline RQ2 & Roquet quarry & 73,4 & 8,2 & 79,8 & 78,6 \\
\hline PI3 & Pielles quarry & 82,3 & 2,6 & 76,2 & 79,9 \\
\hline ROA & Rocamat antique & 76,3 & 2,9 & 72,3 & 70,9 \\
\hline SG2 & Abbey of St Gilles & $*$ & $*$ & $*$ & $*$ \\
\hline EB3 & ST Baudile church & $*$ & $*$ & $*$ & $*$ \\
\hline EPO & Pompignan church & $*$ & $*$ & $*$ & $*$ \\
\hline MMF & War memorial & $*$ & $*$ & $*$ & $*$ \\
\hline EP2 & St Perpetue church & $*$ & $*$ & * & $*$ \\
\hline SP2 & St Paul church & $*$ & $*$ & $*$ & $*$ \\
\hline RA & Rocamat quarry A & 72,9 & 72,3 & 73,5 & 77,5 \\
\hline $\mathrm{RB}$ & Rocamat quarry B & 70,6 & 60,3 & 67,2 & 68,6 \\
\hline $\mathrm{RC}$ & Rocamat quarry $\mathrm{C}$ & 78,9 & 9,7 & 72,1 & 79,1 \\
\hline $\mathrm{RD}$ & Rocamat quarry D & 75,4 & 5,5 & 76,7 & 72,6 \\
\hline \multirow[t]{3}{*}{ RD-2 } & Rocamat quarry D & 72,9 & 7,5 (sanded) & 70,7 & 74,6 \\
\hline & Mean & 75,0 & & 73,3 & 74,8 \\
\hline & Standard deviation & 4,1 & & 4,2 & 4,4 \\
\hline
\end{tabular}

* Too small sample size for capillarity measurement

\subsection{Sulfur diffusion barrier Sulfur EDX mapping of Maison Carrée}

Patinas (Fig. 4b) show a superficial gypsum contamination. Sulfur content decreases suddenly around $600 \mu \mathrm{m}$, which corresponds to the hyphae network layer. Conversely, Patinas of the St Paul's Church is deeply contaminated and has not been colonized by lichens (Fig. 4e). The water flow across stone surface during wetting and drying cycles is the main conveyor of soluble species such as sulfate or calcium ions. Waterproofing due to the growth of lichens can reduce the mass of water flowing through the patina of the stone, and therefore, reduces soluble salts diffusion. 
(a)

Roman Temple (Maison Carrée)

(b)

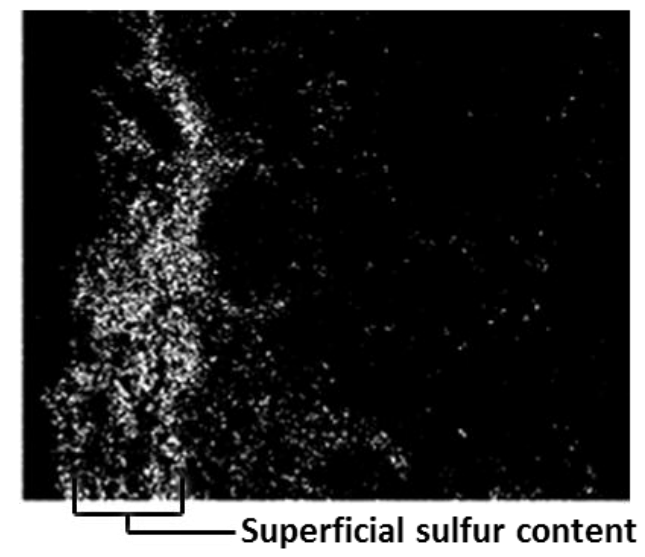

(c)

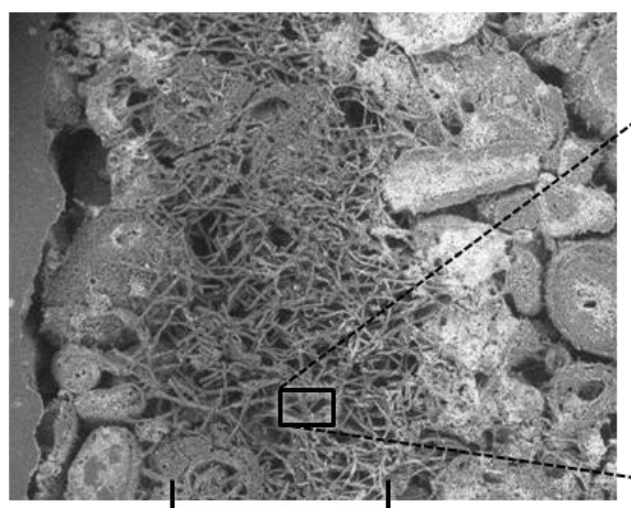

Waterproofing Endolithic hyphae

$1 \mathrm{~mm}$

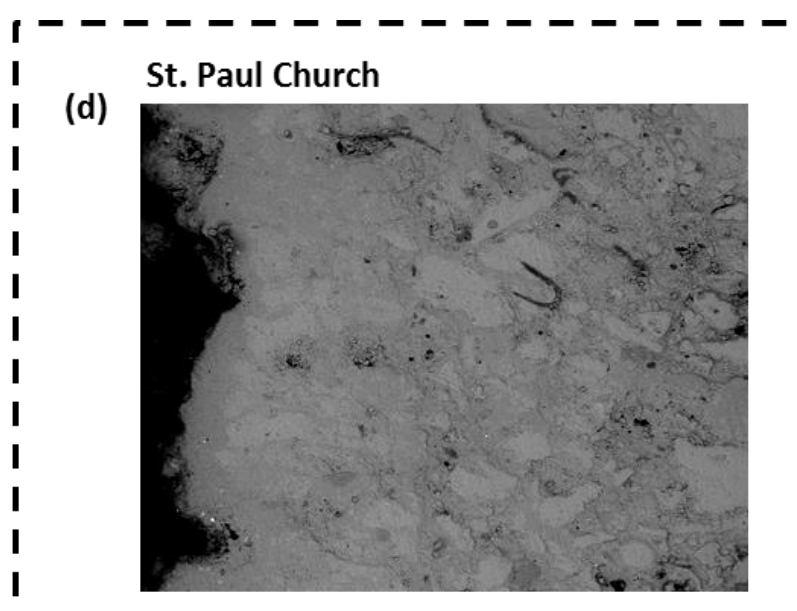

(e)

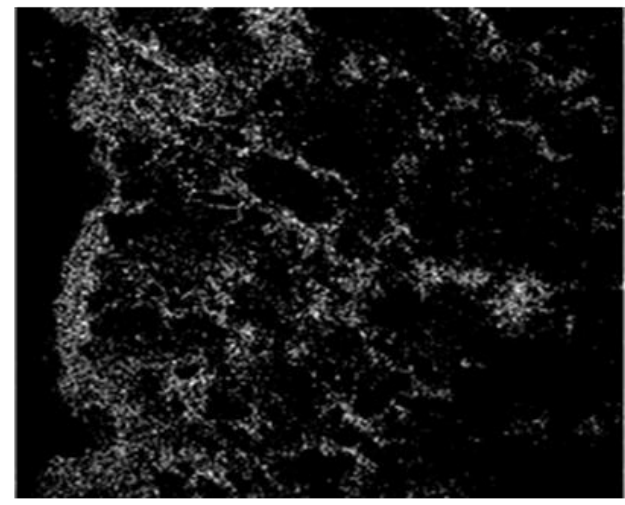

Sulfur diffusion

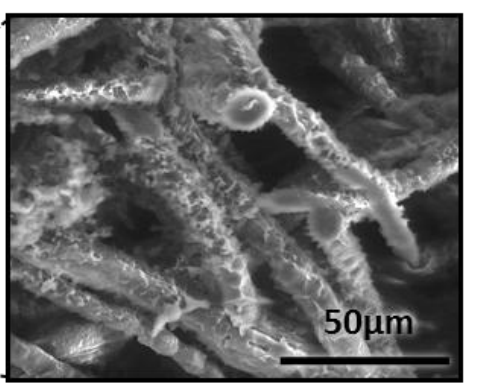

network

Fig. 4. Comparison between a patina of well-preserved monument (left column) and a patina of deteriorated monument (right column). Sulfur distribution along the profile is modified by the hyphae network layer. (a) and (d): SEM. (b) and (e) EDX sulfur map. (c) SEM of pore molding showing a secondary porosity due to growth of endolithic lichen hyphae. 
(a) Roman Temple (Maison Carrée)

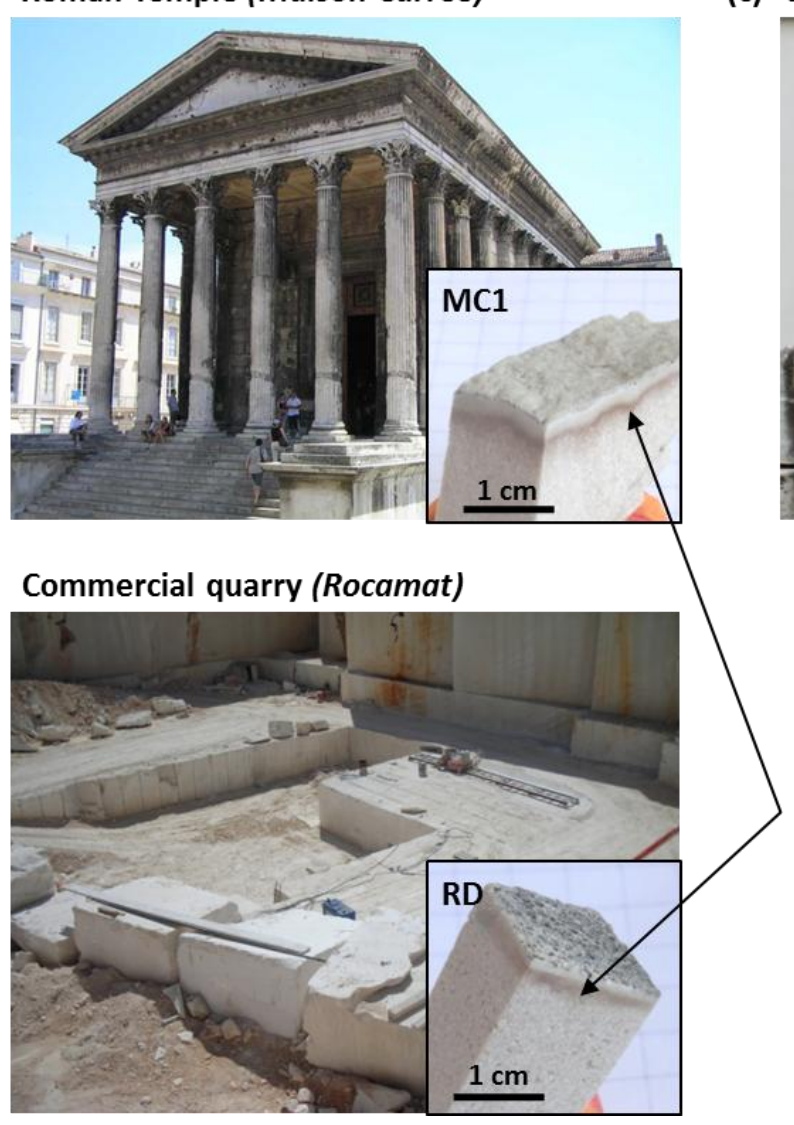

(c) St. Paul Church

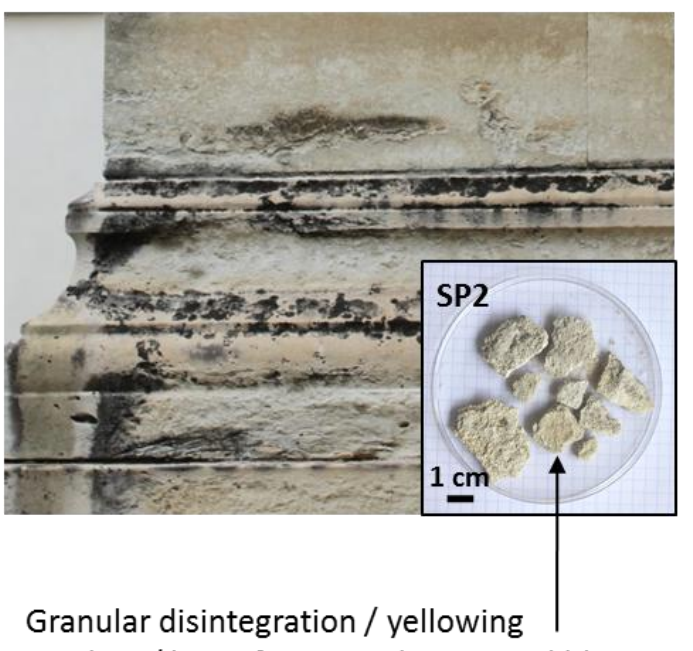

Cracking/ loss of grains cohesion and blistering

Indurated layer

Still cohesive surface

Endolitic hyphae network

Fig. 5. Photographs showing three different samples of Bois des Lens stone patinas. (a) Fac, ade of a Roman temple dating from the 1st century after JC in Nîmes downtown (la Maison Carrée) and detail of a patinated sample (MC1). (c) Front of St Paul's church showing blistering, yellowing and granular disintegration. (b) Stone quarry currently in operation and details of a sample taken from a 50 years working face $(R D)$.

\section{Conclusion}

This study consists in providing some explanations on the weathering differences of the Nîmes downtown monuments built with the same stone focusing on the protective role of organic matter trapped beneath the stone surface. Petro physical characterization of patinas sampled on monuments located in the same neighborhood leads to a classification into two main categories: yellowish patinas that become blistered and disintegrated and on the other hand, patina of well-preserved monuments that maintain a mechanical cohesion. The main pathology of decayed monuments is a loss of mechanical cohesion due to deep gypsum content, especially on the 19th century churches. Regarding the well-preserved monuments, a layer of entrapped organic matter was detected below the surface. Morphological analysis of the porous network by resin molding showed the existence of a secondary porosity filled by 
lichen hyphae. Similar endolithic colonization was observed in stones aged in quarries due to growth of Verrucaria nigrescens and Caloplaca aurantia lichens. The protective role of entrapped organic matter is supported by capillarity measurement that showed a significant pore-sealing waterproofing. Moreover, comparative sulfur content cartography indicates that the waterproofing effect appears to slow down the sulfate diffusion through the stone surface. There is evidence that lichen growth in a previous era is enough to explain the good preservation of some antique monuments of Nîmes.

\section{Acknowledgments}

This research was funded by the civil engineering laboratory of the école des Mines d'Alès. The authors gratefully acknowledge the contribution of E. Garcia-Diaz and L. Tibiletti for their helpful comments. Thank also to J. M. Taulemesse and A. Diaz for their technical support.

\section{References}

[1] M.A. Alvarez de Buergo, R.F. González, Protective patinas applied on stony fac sades of historical buildings in the past, Constr. Build. Mater. 17 (2) (2003) 83-89.

[2] N.E.A. Carter, H.A. Viles, Lichen hotspots: raised rock temperatures beneath Verrucaria nigrescens on limestone, Geomorphology 62 (1-2) (2004) 1-16.

[3] X. Arĩno, J.J. Ortega-Calvo, A. Gomez-Bolea, C. Saiz-Jimenez, Lichen colonization of the Roman pavement at Baelo Claudia (Cadiz Spain): biodeterioration vs bioprotection, Sci. Total. Environ. 167 (1-3) (1995) 353-363.

[4] V. Zafiropulos, Yellowing effect and discoloration of pigments: experimental and theoretical studies, J. Cult. Herit. 4 (2003) 249-256.

[5] G.A. Pope, T.C. Meierding, T.R. Paradise, Geomorphology's role in the study of weathering of cultural stone, Geomorphology 47 (2-4) (2002) 211-225.

[6] ICOMOS-ISCS, Illustrated glossary on stone deterioration patterns, Monuments and Sites: XV, 2008. 
[7] J.C. Bessac, M.R. Aucher, A. Blanc, P. Blanc. La pierre en Gaule Narbonnaise et les carrières du Bois des Lens (Nîmes) : histoire, archéologie, ethnographie et techniques. J. Roman archeology (suppl. 16) (1996) 10-34. [edited by JH Huphrey ISBN 1-887829-16-4].

[8] J.C. Bessac, Les carrières du Bois des Lens (Gard), Gallia 59 (2002) 29-51.

[9] Concha-Lozano N, Lafon D, Eterradossi O, Gaudon P. Assessment of real aging in selection process of replacement materials for stone monuments conservation. 2nd International Meeting on Graphic Archaeology and Informatics, Cultural Heritage and Innovation, Arqueológica 2.0, Sevilla, 14-19 June (2010).

[10] P. Brimblecombe, C.M. Grossi, Aesthetic thresholds and blackening of stone buildings, Sci. Total. Environ. 349 (1-3) (2005) 175-189.

[11] L.A. Naylor, H.A. Viles, N.E.A. Carter, Biogeomorphology revisited: looking towards the future, Geomorphology 47 (1) (2002) 3-14.

[12] N.E.A. Carter, H.A. Viles, Bioprotection explored: the story of a little known earth surface process, Geomorphology 67 (3-4) (2005) 273-281.

[13] T. Warscheid, J. Braams, Biodeterioration of stone: a review, Int. Biodeterioration Biodegradation 46 (4) (2000) 343-368.

[14] P. Griffin, N. Indictor, R. Koestler, The biodeterioration of stone: a review of deterioration mechanisms, conservation case histories, and treatment, Int. Biodeterioration 28 (1-4) (1991) 187-207.

[15] D. Corenblit, A.C.W. Baas, G. Bornette, et al., Feedbacks between geomorphology and biota controlling Earth surface processes and landforms: A review of foundation concepts and current understandings, Earth Sci. Rev. 106 (3-4) (2011) 307-331.

[16] H.D. Kurtz, D.I. Netoff, Stabilization of friable sandstone surfaces in a desiccating, wind-abraded environment of south-central Utah by rock surface microorganisms, J. Arid Environ. 48 (1) (2001) 89-100.

[17] M. Garcia-Vallès, M. Vendrell-Saz, J. Molera, F. Blazquez, Interaction of rock and atmosphere: patinas on Mediterranean monuments, Environ. Geology 36 (1-2) (1998) 137149. 
[18] N.E.A. Carter, H.A. Viles, Experimental investigations into the interactions between moisture, rock surface temperatures and an epilithic lichen cover in the bioprotection of limestone, Build. Environ. 38 (9-10) (2003) 1225-1234.

[19] BRGM, Monumat, http://monumat.brgm.fr. Date of Access: 19/05/2011.

[20] BRGM, 1/50000 Geological map of Sommière.

[21] C. Vazquez-Calvo, M. Alvarez de Buergo, R. Fort, M. Varas, Characterization of patinas by means of microscopic techniques, Mater. Characterization 58 (11-12) (2007) 1119-1132.

[22] R. Dreesen, M. Dusar, Historical building stones in the province of Limburg (NE Belgium): role of petrography in provenance and durability assessment, Mater. Characterization 53 (2-4) (2004) 273-287.

[23] F. Bouchelaghem, A numerical and analytical study on calcite dissolution and gypsum precipitation, Appl. Math. Model. 34 (2) (2010) 467-480.

[24] C. Giavarini, M. Santarelli, R. Natalini, F. Freddi, A non-linear model of sulphation of porous stones: numerical simulations and preliminary laboratory assessments, J. Cult. Herit. 1 (2007) 14-22.

[25] R.A. Lefèvre, A. Ionescu, P. Ausset, et al., Modelling of the calcareous stone sulphation in polluted atmosphere after exposure in the field, Geological Soc. London Spec. Publ. 271 (1) (2007) 131-137.

[26] Á. Török, Surface strength and mineralogy of weathering crusts on limestone buildings in Budapest, Build. Environ. 38 (9-10) (2003) 1185-1192.

[27] K. Beck, M. Al-Mukhtar, Evaluation of the compatibility of building limestones from salt crystallization 